\title{
The Effect of Relational Constructs on Customer Referrals and Number of Services Purchased From a Multiservice Provider: Does Age of Relationship Matter?
}

\author{
Peter C. Verhoef \\ Philip Hans Franses
}

Erasmus University, Rotterdam, The Netherlands

Janny C. Hoekstra

University of Groningen, The Netherlands

\begin{abstract}
The authors examine the effect of relational constructs (e.g., satisfaction, trust, and affective and calculative commitment) on customer referrals and the number of services purchased, as well as the moderating effect of age of the relationship on these relationships. The research reported, based on data obtained from a large sample of customers of an insurance company, combines archival and survey data. The results provide evidence that supports the moderating effect of relationship age on the relationship between satisfaction, affective and calculative commitment, and the number of services purchased.
\end{abstract}

Relationship age has been of interest to relationship marketing researchers for some years now. In a number of studies, the effect of age of the relationship on the level of trust, commitment, and relationship performance has been examined (Anderson and Weitz 1989; Brown, Lusch, and Nicholson 1995; Doney and Cannon 1997; Ganesan 1994; Kumar, Scheer, and Steenkamp 1995a). These studies report mixed results on the effect that age has on these variables. Only recently have studies investigated the

Journal of the Academy of Marketing Science.

Volume 30, No. 3, page 202-216.

Copyright $\odot 2002$ by Academy of Marketing Science. moderating effect of relationship age on the effect that relational constructs, such as trust, satisfaction, and commitment, have on relationship outcomes. These moderating effects are of particular interest from a theoretical and managerial perspective. Theoretically, because longer relationships are qualitatively different from shorter ones, there is a value in research that focuses on the differences between short- and long-term relationships (Grayson and Ambler 1999). Moreover, a study on the moderating effects of relationship age might suggest explanations for diverging findings with regard to the effect of relational constructs on relationship performance (e.g., Doney and Cannon 1999; Gruen, Summers, and Acito 2000; Verbeke, Veldkamp, Bagozzi, and Farris 1999). From the point of view of management, knowledge on how short- and longterm relationships differ can help managers to develop specific strategies for both relationship types. Gaining such knowledge is relatively easy since customer information files can be used to determine this age (Blattberg, Glazer, and Little 1994).

Various studies have considered the time-dependent effect of relational constructs. Bolton (1998) reported that the positive effect of customer satisfaction on relationship duration with a telephone service provider increased with relationship age. Grayson and Ambler (1999) showed that trust solely affected clients' use of services of an 
advertising agency in short-term relationships. No effect of trust was found in long-term relationships. The opposite was found to be true for perceived quality of interactions with the advertising agency. Perceived quality of interactions with the advertising agency only affected clients' use of services in long-term relationships. Grayson and Ambler did not report a moderating effect of relationship age on the effect of commitment. Weiss and Kurland (1997) considered the moderating effect that the age of the dyad has on the effect of transaction-specific investments on relationship continuance in channels. They showed that in longer relationships, the positive effect of manufacturerspecific assets on relationship continuance was increased. Finally, Jap and Ganesan (2000) focused on the moderating effect of the relationship phase on the effect that transaction-specific investments have on commitment. They reported that the positive effect of these investments on commitment was relatively stronger in the exploration phase and the decline phase. Taken together, the studies discussed provide evidence for the notion that the effect of trust, satisfaction, and transaction-specific investments on relationship outcomes is time dependent. However, the moderating effects of relationship age on some constructs, such as payment equity, have not yet been investigated. Moreover, the number of studies investigating the moderating effect of relationship age is relatively small. We do not know whether these effects also hold in contexts other than the ones studied, which are dominated by channels. Moreover, the dependent variables that have been studied are also limited. Our study aims to fill in some of these gaps in the literature.

In this study, we investigate the moderating effect of relationship age on the effect that trust, affective commitment, calculative commitment, satisfaction, and payment equity have on customer referrals and the number of services purchased for a multiservice provider in a businessto-consumer market. In doing so, we extend current knowledge by studying the moderating effect of age. In light of prior research, the moderating effect of relationship age on the relationships between payment equity, payment equity and customer referrals, and payment equity and the number of services purchased is of particular interest. The justification for focusing on customer referrals and the number of services purchased as our dependent variables results from their managerial relevance. These variables are important because of their impact on the monetary value of a customer (Rust, Zeithaml, and Lemon 2000).

Another potential contribution of this research stems from the use of the social psychological literature to explain the moderating effect of relationship age on the relationships between relational constructs and customer behavior. Although it is relatively easy to ascertain the length of a relationship between a customer and a firm from a database, it is not easy to understand or gain meaningful knowledge about how short- and long-term relationships differ. The conflicting findings in the literature also attest to this. In this research, we aim to resolve this problem by using a social psychological perspective to shed insight into the moderating effect of relationship age (Gill, Swann, and Silvera 1998; Swann and Gill 1997). Since studies in social psychology focus on the effect that relationship age has on how confidence in one's beliefs affects customer behavior, this literature provides a theoretical basis for understanding the moderating effect of relationship age.

Although there is a growing trend toward using archival data in customer satisfaction research (e.g., Bolton 1998; Bolton, Kannan, and Bramlett 2000), the use of archival data is less pronounced in research on marketing relationships. Notable exceptions are studies by Gruen et al. (2000); Kumar, Stern, and Achrol (1992); Kumar, Hibbard, and Stern (1994); and Hibbard, Kumar, and Stern (2001). The use of archival data in the research reported provides us with the opportunity to investigate whether empirical results of studies relating relational constructs to self-reported behavior, such as purchase intentions, can be replicated when we relate these constructs to data from a customer database. The associations between these constructs and archival data are not susceptible to being inflated by common-method variance problems, which is often the case when self-reported behavior is studied.

We continue with a discussion of our conceptual model and the hypotheses. Next, we describe the research methodology of our empirical study. The empirical results are presented subsequently. We conclude with a discussion and an assessment of managerial implications, limitations, and directions for future research.

\section{HYPOTHESES}

An overview of the proposed conceptual framework is displayed in Figure 1. Here, we consider two behavioral relationship outcomes: customer referrals and number of services purchased. Customer referrals are defined as the extent to which customers advise other customers (e.g., friends, family, colleagues) to do business with the focal supplier. The number of services purchased is a count of different services purchased by a customer from a multiservice provider. We expect these outcomes to be affected by trust, affective commitment, calculative commitment, satisfaction, and payment equity. Furthermore, we expect that these effects are time dependent.

\section{Main Effects}

\section{Trust}

Trust is generally viewed as a key element of successful relationships (e.g., Berry 1995; Morgan and Hunt 1994). 
FIGURE 1

Effect of Relational Constructs on Relationship Outcomes and the Moderating Effect of Relationship Age

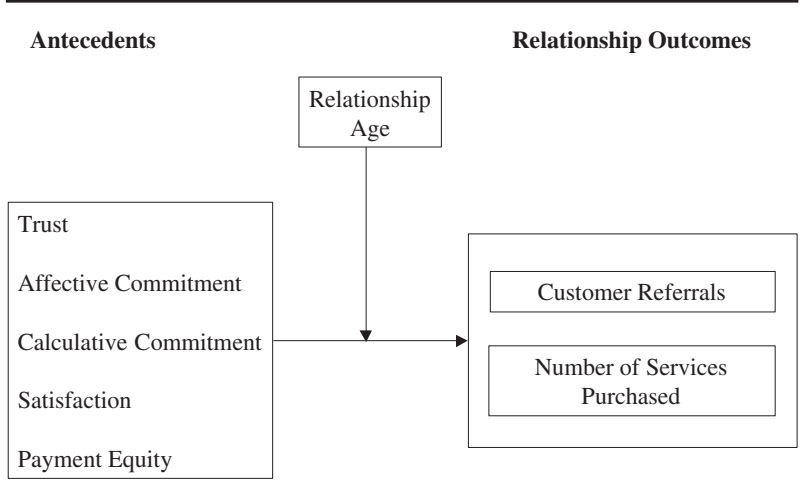

Morgan and Hunt (1994:23) defined trust as the perception of confidence in an exchange partner's reliability and integrity. Other definitions of trust also highlight the importance of confidence and reliability (e.g., Moorman, Zaltman, and Desphandé 1992). In line with Garbarino and Johnson (1999), our study focuses on customer confidence in the quality and reliability of the services provided. This confidence is a rather important relational benefit for customers in the service industry (Gwinner, Gremler, and Bitner 1999). Morgan and Hunt (1994:22) have argued that trust leads to cooperative behavior that is conducive to relationship marketing success. Empirical studies provide conflicting evidence with respect to the effect of trust on relationship outcomes. On one hand, researchers report significant positive effects of trust on selfreported measures of relationship continuity (e.g., Anderson and Weitz 1989; Doney and Cannon 1997; Ganesan 1994; Garbarino and Johnson 1999; Morgan and Hunt 1994). In a service context, Gwinner et al. (1999) reported that trust is positively related to customer referrals. On the other hand, researchers in the channel area find only weak or no significant effects of trust on behavioral outcomes of a relationship, such as resource allocation and purchase choice (e.g., Anderson, Lodish, and Weitz 1987; Doney and Cannon 1997; Verbeke et al. 1999). This might, however, be due to the fact that these studies do not account for the time-dependent nature of trust. ${ }^{1}$ Because we take this nature of trust into account, and because trust is thought to be a key element for successful relationships, we hypothesize the following main effects of trust:

Hypothesis 1a: Trust is positively related to customer referrals.

Hypothesis $1 b$ : Trust is positively related to the number of services purchased.

\section{Commitment}

Commitment is defined as involving an exchange partner who believes that an ongoing relationship with another is important enough to warrant maximum efforts at maintaining it (Morgan and Hunt 1994:23). We distinguish between two components of commitment: affective and calculative commitment (Brown et al. 1995; Geyskens, Steenkamp, Scheer, and Kumar 1996; Gundlach, Achrol, and Mentzer 1995; Kumar et al. 1994). Affective commitment refers to the psychological attachment of an exchange partner to the other and is based on feelings of identification, loyalty, and affiliation (Gundlach et al. 1995). Calculative commitment, by contrast, is defined as the extent to which exchange partners perceive the need to maintain a relationship given the anticipated termination or switching costs associated with leaving (Geyskens et al. 1996:304). Thus, switching costs or relationship termination costs are considered as important antecedents of calculative commitment.

Since affectively committed customers feel attached to the organization because of positive feelings, it is argued that these customers will display positive behavior for the organization. There is evidence in the literature that affective commitment is positively related to customers' voluntary behavior (Bettencourt 1997). Hence, we expect a positive relationship between affective commitment and customer referrals. Affective commitment is also found to affect relational outcomes, such as customer share (Odekerken-Schröder 1999) and relationship performance (Kumar et al. 1994). Moreover, Sheth and Parvatiyar (1995:256) have stated that as the consumer becomes more committed to a relationship, he or she will be less likely to patronize other marketers. Hence, we also expect a positive relationship with the number of services purchased.

Because calculative commitment can be considered a negative motivation to continue a relationship (Geyskens et al. 1996), customers with a high level of calculative commitment should not be expected to advise other consumers to do business with the supplier. One might even argue that given the negative nature of calculative commitment it could lead to negative referrals (Kumar et al. 1994). The link between calculative commitment and the number of services purchased is not straightforward. Kumar et al. (1994) reported no association between calculative commitment and relationship performance. However, switching costs are acknowledged as drivers of behavioral loyalty (Dick and Basu 1994; Klemperer 1995). Hence, we expect a positive relationship between calculative commitment and the number of services purchased. We hypothesize the following:

Hypothesis 2a: Affective commitment is positively related to customer referrals. 
Hypothesis 2b: Affective commitment is positively related to the number of services purchased.

Hypothesis 3a: Calculative commitment is negatively related to customer referrals.

Hypothesis $3 b$ : Calculative commitment is positively related to the number of services purchased.

\section{Satisfaction}

Crosby, Evans, and Cowles (1990) referred to relationship satisfaction in a service context as "an emotional state that occurs in response to an evaluation of interaction experiences" (p. 70). This is more or less in line with the definition of overall satisfaction by Anderson, Fornell, and Lehmann (1994), who stated that "overall satisfaction is an overall evaluation based on the total purchase and consumption experience with a good or service over time" (p. 54). Hence, satisfied customers highly value the offered services (Bolton and Lemon 1999). For this reason, they will be more inclined to behave in a way that is beneficial to the company. A number of empirical studies support this finding by reporting positive effects of satisfaction on customer referrals, purchase intentions, usage of a service, and relationship duration (e.g., Bettencourt 1997; Bolton 1998; Bolton and Lemon 1999; Zeithaml, Berry, and Parasuraman 1996). In a meta-analysis, Szymanski and Henard (2001) showed that customer satisfaction is negatively related to negative word-of-mouth communication. Hence, we expect customer satisfaction to be positively related to customer referrals. Given the positive effect of customer satisfaction on purchase behavior (e.g., purchase intentions, usage), we also expect that satisfaction will be positively related to the number of services purchased. Hence, we hypothesize the following:

Hypothesis 4a: Satisfaction is positively related to customer referrals.

Hypothesis 4b: Satisfaction is positively related to the number of services purchased.

\section{Payment Equity}

Payment equity is customers' perceived fairness of the price paid for their consumed services (Bolton and Lemon 1999). Bolton and Lemon (1999) and Bolton et al. (2000) have studied the effect of payment equity on service usage and retention. One would expect that in the case of high payment equity, customers are more likely to consume more services and also share information about the attractive price with other consumers. We argue that the effect of payment equity and the number of services purchased might be less straightforward in multiservice industries. In these industries, customers are often attracted by lowpriced services. ${ }^{2}$ These customers might find the prices of these purchased services to be quite fair. But this does not have to be true for the other services, which might lead to reluctance to buy additional (higher priced) services. Furthermore, in the literature on pricing, Lichtenstein,
Ridgway, and Netemeyer (1993) suggested that perceptions of prices are positively related to price seeking. In this connection, Bolton and Lemon (1999:182) suggested that customers in service industries should seek to maintain payment equity in the service relationship. Hence, customers with high payment equity scores will be less likely to purchase additional higher priced services. Although we acknowledge this possible effect, we follow prior research that reports a positive effect of payment equity on service usage (Bolton and Lemon 1999) and hypothesize the following:

Hypothesis 5a: Payment equity is positively related to customer referrals.

Hypothesis 5b: Payment equity is positively related to the number of services purchased.

\section{Moderating Effect of Age of the Relationship}

Our discussion of the moderating effect of relationship age on the main effects draws mainly from two streams of literature: (1) studies in social psychology, which show that the length of the relationship is positively related to confidence in one's evaluations of the partner (Swann and Gill 1997), and (2) literature on relationship marketing, which shows that buyer-seller relationships go through different phases. For instance, Dwyer, Schurr, and Oh (1987) suggested that each relationship phase represents a major transition of how parties regard one another, and in the different phases, different variables are important in explaining the success of relationships. Although relationship age is not perfectly correlated with relationship phase, a number of studies investigating the moderating effect of relationship age (Grayson and Ambler 1999; Weiss and Kurland 1997) use the theory of Dwyer et al. (1987) to develop their hypotheses. In this study, we build on the empirical results reported in these studies.

Trust

In the early phases of a relationship, customers do not have much experience with the company. Hence, the richness of their impressions of the company is rather small (Swann and Gill 1997). As a result, it will be hard for customers to base their behavior on the evaluation of their experience. Hence, customers will rely on the perceived trustworthiness of the supplier, placing their confidence in the reliability and quality of the services provided by the supplier (Garbarino and Johnson 1999). In the early phases of a relationship, companies try to shape customers' perceived trustworthiness by using advertising, brand names, and other signals. It is for this reason that Jap (1999) argued that trust will be essential in the early phases of the relationship. As noted earlier, Grayson and Ambler (1999) reported that trust positively affects the clients' use of advertising agency services in short-term relationships. Their study also shows that evaluations of interactions 
with the advertising agency become more important in long-term relationships. Thus, we expect trust to have a larger positive effect on customer referrals and the number of services purchased in short-term relationships. We hypothesize the following:

Hypothesis 6a: Relationship age reduces the positive effect of trust on customer referrals and the number of services purchased.

\section{Commitment}

Affectively committed customers identify themselves with and feel affiliated to the organization (Gundlach et al. 1995). Stated differently, affectively committed customers will have relatively intimate relationships with the company. This intimacy only develops over the long run (Dwyer et al. 1987; Geyskens, Steenkamp, and Kumar 1999). As the relationship matures and becomes more intimate, customers will have acquired more information about the company, leading to an increased richness of the customer's impressions about the supplier (Swann and Gill 1997). This increased richness leads to an increasing confidence in the beliefs about the relationship with the supplier (Gill et al. 1998). This increasing confidence enhances the impact of these beliefs (Berger and Mitchell 1989; Dick and Basu 1994; Pieters and Verplanken 1995). Hence, we expect that relationship age will increase the effect of affective commitment on both customer referrals and the number of services purchased. We hypothesize the following:

Hypothesis 6b: Relationship age increases the positive effect of affective commitment on customer referrals and the number of services purchased.

Switching costs arise from a number of sources, such as transaction costs, costs of learning to buy from new suppliers, and uncertainty of the quality of other suppliers (Klemperer 1995). During a relationship, customers become familiar and experienced in interacting with the supplier and their procedures. Due to this learning process, customers get locked into the relationship (Nilssen 2000; Shapiro and Varian 1999). This suggests that calculative commitment itself might increase with relationship age, but it does not automatically imply an enhancing effect of relationship age on the effect that calculative commitment has on relationship outcomes. A rationale for this enhancing effect might again be based on the previously discussed studies in social psychology (e.g., Swann and Gill 1997). Customers with longer term relationships will not only have more switching costs as the relationship gets longer, but they probably are also more aware of these switching costs and are more confident that these switching costs are relevant to their relationship with the supplier. This increased confidence in the relevance of switching costs would perhaps lead to an enhancing effect of rela- tionship age on the effect of calculative commitment. In a channel context, Weiss and Kurland (1997) indeed found that the relationship between switching costs and relationship continuation is enhanced by relationship age. Thus, we hypothesize the following:

Hypothesis 6c: Relationship age increases the negative effect of calculative commitment on customer referrals and the positive effect of calculative commitment on the number of services purchased.

\section{Satisfaction}

As noted earlier, the richness of customers' impressions about the supplier increases as the relationship ages, which causes increasing confidence in customers' evaluations of the supplier (Swann and Gill 1997). Gill et al. (1998) also noted that people in long-lasting relationships have considerable confidence in their evaluations of their partners, regardless of whether those beliefs are accurate. Thus, although customers with lengthy relationships may have erroneous evaluations of the supplier, they tend to be more confident about these evaluations. It is, of course, also true that in the early stages of the relationship, customers have less confidence in their evaluation of the supplier. Therefore, direct experiences from interactions with the supplier should be more powerful predictors of relationship outcomes in lengthy relationships (Jap 1999). Empirical findings in the relationship marketing literature support this reasoning. Grayson and Ambler (1999) showed that the evaluations of interactions only affect the use of a marketing service in lengthy relationships. Bolton (1998) reported that the positive effect of satisfaction on relationship duration is enhanced by relationship age. Rust, Inman, Jia, and Zahorik (1999) also suggested that the effect of satisfaction is larger in lengthy relationships. Following the above reasoning and empirical evidence, we hypothesize the following:

Hypothesis 6d: Relationship age increases the positive effect of satisfaction on customer referrals and the number of services purchased.

\section{Payment Equity}

Customers are said to be more value conscious in lengthy relationships (Reinartz and Kumar 2000). Hence, customers with lengthy relationships will pay more attention to the price paid for their services, suggesting a stronger effect of payment equity in lengthy relationships. A rationale for this stronger effect can again be found in social psychology studies (Swann and Gill 1997). In longer relationships, customers will perhaps have greater confidence in their evaluations of the price paid for their services. Hence, they will rely more strongly on this evaluation in later phases of the relationship, and we hypothesize that the effect of payment equity will be enhanced in lengthy relationships. 
Hypothesis 6e: Relationship age increases the positive effect of payment equity on customer referrals and the number of services purchased.

\section{RESEARCH METHOD}

\section{Data Collection and Sample}

The data were collected by phone, using a keyinformant approach from a proportional stratified sample of 6,525 customers of an insurance company in the Netherlands. This company solely uses the direct channel to sell its services. Besides insurance, it also sells some financial products, such as loans, but more than 75 percent of its turnover is gained from selling insurance. The bases for stratification were relationship age, purchase level of services, and claiming behavior. Using this sample methodology, we obtained a representative sample based on these three characteristics. The final sample size is 2,300 (response rate $=35 \%$ ), as 23 percent refused to participate, 24 percent could not be reached due to the wrong phone number or they were not at home, and 18 percent were not able to participate due to language or other problems. After deleting the cases with too many missing values, a sample size of 1,986 customers remained. Mean substitution was used to replace the remaining missing values (Hair, Anderson, Tatham, and Black 1998). In line with the characteristics of customers of the company, the individuals in the sample could be described as rather prosperous and well educated. The average relationship age of the respondents was approximately 10 years, while the average number of services purchased was approximately 2.4 .

\section{Measure Development}

As most of the literature on relationship marketing concerns channels and/or very specific customer environments (Garbarino and Johnson 1999), we adapted measurements used in both contexts. We used a five-step procedure to develop our measurements (Churchill 1979; Steenkamp and van Trijp 1991).

In Step 1, items were generated based on a literature review. Ten items from the scale that measure trust were adapted from Crosby et al. (1990), Garbarino and Johnson (1999), and Kumar, Scheer and Steenkamp (1995b). The chosen items mainly focus on the customers' confidence in the quality and reliability of the services provided (Garbarino and Johnson 1999). We adapted eight items from Anderson and Weitz (1992), Garbarino and Johnson (1999), and Kumar et al. (1995b) for the measurement of affective commitment. With these items, we tried to capture the customers' desire to remain with the company because of feelings of attachment, identification, and loyalty. Items such as, "Because I feel a strong attachment to company XYZ, I remain customer of XYZ," especially focused on this. Calculative commitment was measured with six items adapted from Geyskens et al. (1996) and Kumar et al. (1994). These items reflect the desire to remain a customer for economic reasons, such as switching costs. We adapted four items from Singh (1990) and added four items with regard to responsiveness for measuring satisfaction. For the measurement of payment equity, we focused on the insurance premium evaluation using items from Singh (1990) and Bolton and Lemon (1999). Customer referrals were measured with three items adapted from Zeithaml et al. (1996). All items are shown in the appendix.

In Step 2, we provided the marketing academics and marketing practitioners with an overview of the initial items and the definitions of the constructs we aimed to measure with these items. We asked them to consider the wording. To ensure the internal validity of the scale, we asked whether they thought the selected items measured the underlying constructs. For all items considered, the experts stated that these items might be good indicators for our considered constructs.

In Step 3, we tested the items among a sample of 200 customers using a telephone survey. To minimize carryover effects, we presented all items randomly to the customers using computer-assisted telephone interviewing (CATI) (Bickart 1993).

In Step 4, we reduced the number of items based on content and the following statistical criteria: (1) interitem correlations, (2) item-to-total correlations, (3) coefficient alpha, (4) exploratory factor analysis using varimax rotation, and (5) confirmatory factor analysis. With respect to trust, we selected four items. These items mainly focused on the reliability and quality of the services. For affective commitment, we selected three items in the pretest. All items focused on feelings of attachment, belonging, and loyalty to the company. One item was excluded because, in retrospect, it did not appear to measure affective commitment very well, as it did not capture the feelings of loyalty and attachment. From the items measuring calculative commitment, we selected four items. One excluded item focused on the role of monetary costs as a reason to remain a customer. Customers were probably not aware of these monetary costs because these costs come into play only when insurance is in fact terminated. Consultation with the marketing manager at the company indeed revealed that this might be the case. The other excluded item was reversed and seemed to capture more of an inertia effect (i.e., habitual behavior) than switching costs. For satisfaction, only one item that measured satisfaction about the claiming procedure was excluded. This can be explained by the fact that not all customers had enough experience with this procedure. 


\section{Validation of Measures}

In Step 5, the remaining items after the pretest were included in the survey among the 2,300 customers. To validate these measures, we followed the well-known fourstep procedure as described in Gerbing and Anderson (1988). After computing the coefficient alpha and item-tototal correlations and applying exploratory factor analysis for each scale separately, all remaining items after the pretest were taken into our confirmatory factor analysis. We tested the measurement model using LISREL83 with a covariance matrix as input (Jöreskog and Sörbom 1993). We deleted one item from the calculative commitment scale, as this substantially increased the model fit and the item had a standardized factor loading below 0.5 . The final model fit of the measurement model satisfies most of the stated criteria in the literature with a $\chi^{2}$ of $847.34(d f=194$, $p=.00)$, a $\chi^{2} / d f$ of $4.36(d f=1, p<.05)$, a Goodness-of-Fit Index (GFI) of 0.96, an Adjusted Goodness-of-Fit Index (AGFI) of 0.95, a Comparative Fit Index (CFI) of 0.96, and a root mean square error of approximation (RMSEA) of 0.042 (Bagozzi and Yi 1988; Baumgartner and Homburg 1996). The $\chi^{2}$ indices are the only fit statistics that do not comply with these criteria. Note that these indices are fairly strongly correlated with sample size and are therefore problematic to use for the assessment of model fit in large samples (Bentler 1990; Baumgartner and Homburg 1996). The final results of our measurement model are reported in Table 1. The coefficient alphas, means, standard deviations of the scales, and the intercorrelations are reported in Table 2.

To assess the convergent validity of each construct, we examined the sign, size, and significance of the estimated factor loadings. We computed the composite reliability index and average variance extracted to assess how well each construct is measured by its indicators. Each standardized factor loading had the right sign and was highly significant $(p<.01)$. All factor loadings are larger than 0.5 . The composite reliabilities of all constructs lie above 0.7 , while the average variance extracted for each construct is larger than 0.4. On the basis of these results, we conclude that our constructs are reliable and unidimensional (Bagozzi and Yi 1988; Gerbing and Anderson 1988).

The assessment of discriminant validity of the measurements used is important, as there is a debate on the differences between the constructs employed (Garbarino and Johnson 1999). Constraining the estimated correlation parameter between two constructs to 1.0 and then performing a chi-square difference test on the values for the constrained and unconstrained model has been used to assess discriminant validity. This procedure was performed for each pair of factors at a time (Anderson and Gerbing 1988). Using this procedure, we found for each pair significantly lower chi-squares for the unconstrained models. Thus, discriminant validity appears to have been achieved. Additional evidence for discriminant validity was provided by the fact that none of the confidence intervals for the correlation estimates between the separate pairs of factors included the value of 1.0.

\section{Measurement of Number of Services Purchased and Relationship Age}

The number of services purchased is directly observable in the customer database. It is calculated by counting the number of purchases of different types of services from the supplier in October 1999. Relationship age data are also available from the customer database. These data are calculated as the interval between the time of measurement and the starting date of the relationship in years (see Bolton 1998).

\section{Analysis}

The hypotheses with respect to customer referrals were tested in a regression model, where the parameters have been estimated using ordinary least squares (OLS). The hypotheses with regard to the number of services purchased were tested with a Poison regression model using maximum likelihood (Long 1997) ${ }^{3}$ because the dependent variable, number of services purchased, is a count outcome. Both models were estimated with the software package E-views 4. All scales with multiple items were averaged to form composite scales. We included the natural logarithm of relationship age in our models, as it is assumed that the effect of relationship length is not linear (i.e., length has diminishing effects at higher levels) (Weiss and Kurland 1997). The composite scales and the logarithm of relationship age are mean centered (Aiken and West 1991). The presence of the moderating effect of relationship age on the studied main effects was tested with the inclusion of interaction terms between relationship age and the relational constructs (Aiken and West 1991). To control for the effects of sociodemographic variables on the number of services purchased, we also included covariates in the regression model, such as age, household size, and income (Kamakura, Ramaswami, and Srivastava 1991). Also, to end up with a parsimonious model, we decided to include only those covariates in the model that have a $p$ value below .20. Finally, we considered a twosided $p$ value equal to or below .05 and the hypothesized sign for the estimator as evidence for our hypothesis.

\section{EMPIRICAL RESULTS}

The results of the regression analysis (OLS) and the Poisson regression analysis are reported in Table 3. 
TABLE 1

Measurement Model Evaluations $(n=1,986)$

\begin{tabular}{|c|c|c|c|c|}
\hline & $\begin{array}{l}\text { Standardized } \\
\text { Loading }\end{array}$ & $\mathrm{t}$ Value & $\begin{array}{l}\text { Composite } \\
\text { Reliability }\end{array}$ & $\begin{array}{l}\text { Average } \\
\text { Variance } \\
\text { Extracted }\end{array}$ \\
\hline Affective commitment & & & 0.78 & 0.55 \\
\hline I am a loyal customer of XYZ. & 0.58 & - & & \\
\hline Because I feel a strong attachment to XYZ, I remain a customer of XYZ. & 0.79 & 23.98 & & \\
\hline $\begin{array}{l}\text { Because I feel a strong sense of belonging with XYZ, I want to remain a customer } \\
\text { of XYZ. }\end{array}$ & 0.84 & 24.19 & & \\
\hline Calculative commitment & & & 0.75 & 0.53 \\
\hline $\begin{array}{l}\text { Because it is difficult to stop my insurance at XYZ, I remain a customer of XYZ. } \\
\text { I remain a customer of XYZ because it is difficult to take my insurance to another }\end{array}$ & 0.70 & - & & \\
\hline insurance company. & 0.80 & 22.49 & & \\
\hline $\begin{array}{l}\text { I remain a customer of XYZ because it costs much time and energy to switch my } \\
\text { insurance to another insurance company. }\end{array}$ & 0.62 & 22.16 & & \\
\hline Trust & & & 0.76 & 0.45 \\
\hline $\mathrm{XYZ}$ can be relied on to keep its promises. & 0.71 & - & & \\
\hline XYZ puts the customer's interest first. & 0.55 & 21.55 & & \\
\hline XYZ usually keeps the promises that it makes to me. & 0.68 & 25.86 & & \\
\hline I can count on XYZ to provide a good service. & 0.74 & 27.45 & & \\
\hline Satisfaction & & & 0.83 & 0.42 \\
\hline How satisfied are you about the following $(1=$ very dissatisfied, $5=$ very satisfied $) ?$ & & & & \\
\hline Personal attention of XYZ & 0.65 & - & & \\
\hline Willingness of XYZ to explain procedures & 0.55 & 21.82 & & \\
\hline Service quality of XYZ & 0.73 & 26.30 & & \\
\hline Response to claims & 0.54 & 20.97 & & \\
\hline Expertise of the personnel of XYZ & 0.63 & 23.96 & & \\
\hline Your relationship with XYZ & 0.71 & 26.22 & & \\
\hline Alertness of XYZ & 0.70 & 25.88 & & \\
\hline Payment equity & & & 0.88 & 0.56 \\
\hline $\begin{array}{l}\text { How satisfied are you about the insurance premium } \\
(1=\text { very dissatisfied, } 5=\text { very satisfied }) ?\end{array}$ & 0.90 & - & & \\
\hline $\begin{array}{l}\text { Do you think the insurance premium of your insurance is too high, high, normal, low, } \\
\text { or too low? }\end{array}$ & 0.55 & 8.27 & & \\
\hline Customer referrals & & & 0.73 & 0.48 \\
\hline I say positive things about XYZ to persons in my environment. & 0.67 & - & & \\
\hline If somebody seeks for advice with regard to a good insurance company, & & & & \\
\hline I recommend XYZ. & 0.78 & 24.55 & & \\
\hline I encourage relatives and friends to do business with XYZ. & 0.63 & 21.60 & & \\
\hline
\end{tabular}

TABLE 2

Means, Standard Deviations, Reliabilities, and Intercorrelations $(n=1,986)$

\begin{tabular}{|c|c|c|c|c|c|c|c|c|c|c|c|}
\hline & Mean & $\begin{array}{l}\text { Standard } \\
\text { Deviation }\end{array}$ & $\begin{array}{c}\text { Coefficient } \\
\text { Alpha }\end{array}$ & $X 1$ & $X 2$ & X3 & $X 4$ & $X 5$ & $X 6$ & $Y 1$ & $Y 2$ \\
\hline Trust (X1) & 3.78 & 0.45 & 0.75 & 1.00 & & & & & & & \\
\hline Affective commitment (X2) & 2.96 & 0.78 & 0.77 & 0.39 & 1.00 & & & & & & \\
\hline Calculative commitment (X3) & 2.47 & 0.69 & 0.74 & 0.02 & 0.15 & 1.00 & & & & & \\
\hline Satisfaction (X4) & 3.75 & 0.45 & 0.83 & 0.58 & 0.38 & -0.01 & 1.00 & & & & \\
\hline Payment equity (X5) & 3.42 & 0.56 & 0.66 & 0.18 & 0.14 & -0.07 & 0.20 & 1.00 & & & \\
\hline Log of relationship age (X7) & 1.00 & 1.81 & - & 0.07 & 0.07 & 0.01 & 0.08 & -0.08 & 1.00 & & \\
\hline Customer referrals (Y1) & 3.47 & 0.60 & 0.71 & 0.49 & 0.50 & 0.03 & 0.44 & 0.21 & 0.04 & 1.00 & \\
\hline Number of services purchased (Y2) & 2.40 & 1.90 & - & 0.02 & 0.10 & -0.02 & 0.07 & 0.04 & 0.33 & 0.12 & 1.00 \\
\hline
\end{tabular}

Variance inflation factors (VIF) scores were computed for both models to check for multicollinearity. The computed VIF scores have values between 1 and 2 . Hence, we conclude that multicollinearity has not affected our estimates, and we can safely test the hypotheses (Hair et al. 1998). 
TABLE 3

Results of Regression Analysis

\begin{tabular}{|c|c|c|c|c|c|}
\hline & \multirow[b]{2}{*}{ Hypothesis } & \multicolumn{2}{|c|}{ Customer Referrals $(\mathrm{n}=1,946)^{\mathrm{a}}$} & \multicolumn{2}{|c|}{$\begin{array}{l}\text { Number of Services Purchased } \\
\qquad(\mathrm{n}=1,946)^{\mathrm{b}}\end{array}$} \\
\hline & & $\begin{array}{c}\text { Unstandardized } \\
\text { Estimate }\end{array}$ & Absolute t Value & $\begin{array}{l}\text { Unstandardized } \\
\text { Estimate }\end{array}$ & Absolute z Value \\
\hline Intercept & - & 3.46 & $317.83 * *$ & 0.90 & $17.20 * *$ \\
\hline Relationship age & - & -0.01 & -1.33 & 0.24 & $16.49^{* *}$ \\
\hline Trust & $1 \mathrm{a}, 1 \mathrm{~b}$ & 0.34 & $9.58 * *$ & -0.08 & 1.84 \\
\hline Affective commitment & $2 a, 2 b$ & 0.25 & $15.73^{* *}$ & 0.06 & $2.59 * *$ \\
\hline Calculative commitment & $3 a, 3 b$ & -0.01 & -1.13 & -0.01 & 0.40 \\
\hline Satisfaction & $4 \mathrm{a}, 4 \mathrm{~b}$ & 0.21 & $6.92 * *$ & 0.06 & 1.36 \\
\hline Payment equity & $5 a, 5 b$ & 0.09 & $4.35 * *$ & 0.06 & $2.29 * *$ \\
\hline Relationship Age $\times$ Trust & $6 a$ & 0.00 & 0.13 & 0.01 & 0.21 \\
\hline Relationship Age $\times$ Affective Commitment & $6 b$ & 0.00 & 0.56 & 0.05 & $2.45^{* *}$ \\
\hline Relationship Age $\times$ Calculative Commitment & $6 \mathrm{c}$ & -0.02 & -1.15 & -0.04 & $1.97 *$ \\
\hline Relationship Age $\times$ Satisfaction & $6 \mathrm{~d}$ & -0.01 & -0.34 & 0.08 & $2.00 *$ \\
\hline Relationship Age $\times$ Payment Equity & $6 e$ & 0.01 & 0.54 & -0.04 & 1.55 \\
\hline \multicolumn{6}{|l|}{ Covariates } \\
\hline \multicolumn{6}{|l|}{ Income } \\
\hline Low income & - & - & - & -0.24 & $3.88 * *$ \\
\hline Middle income & - & - & - & -0.12 & $3.01 * *$ \\
\hline High income & - & - & - & -0.03 & 0.78 \\
\hline Very high income & - & - & - & 0.004 & 0.10 \\
\hline Number of cars & - & - & - & -0.02 & -1.51 \\
\hline$R^{2}$ & 0.37 & & 0.15 & & \\
\hline Adjusted $R^{2}$ & & 0.37 & & 0.14 & \\
\hline$F$ value ( $p$ value)/likelihood ratio statistic & & 105.71 & $(0.00)$ & 334.87 & $(0.00)$ \\
\hline
\end{tabular}

a. Ordinary least squares regression model estimated with White's (1980) correction for heteroscedasticity.

b. Poisson regression model estimated with White's (1980) correction for heteroscedasticity.

$* p<.05$. ** $p<.01$.

The joint contribution of the exploratory variables is significant, considering that the $F$ value is $105.71(p=.00)$ and the likelihood ratio statistic is $334.9(p=.00)$. The customer referral model explains 37 percent of the variance, and the number of services purchased model explains 15 percent of the variance. The large difference in $R^{2}$ between these two models can be explained by the fact that in the model explaining the number of services purchased, there is a lack of shared variance between the relational constructs and the dependent variable. However, there is shared variance between the relational constructs and the customer referral measurement because these variables are measured within the same survey. The large difference in $R^{2}$ is in line with results of Kumar et al. (1994). The low explanatory power of models explaining archival data is not uncommon in this research area. Gruen et al. (2000) also explained only a small part of the variance in customer retention. Moreover, our $R^{2}$ is comparable with the $R^{2}$ reported in Mittal and Kamakura (2001).

In the model explaining the number of services purchased, we find positive significant effects of income and a small nonsignificant effect of the number of cars. This finding is in line with the results of Kamakura et al. (1991), who reported that financial maturity is positively associated with income and house ownership, among other variables.

\section{Customer Referrals: Main Effects}

Confirming results of previous studies, no significant relationship between relationship age and customer referrals was found ( $\beta=-.01, p=.18$ ) (e.g., Kumar et al. 1995a). We found highly significant positive coefficients for trust $(\beta=$ $.34, p=.00)$, affective commitment $(\beta=.25, p=.00)$, satisfaction $(\beta=.21, p=.00)$, and payment equity $(\beta=.09, p=$ $.00)$. Hence, we found support for Hypotheses 1a, 2a, 4a, and $5 \mathrm{a}$. With respect to calculative commitment, we found a negative nonsignificant coefficient $(\beta=-.02, p=.26)$. Thus, our data do not provide support for Hypothesis $3 \mathrm{a}$.

\section{Customer Referrals: Moderator Effects}

The results of the customer referral model reveal no significant interaction effects between relationship age and the relational constructs. ${ }^{4}$ Thus, our results do not support our hypotheses that suggested that relationship age moderated the effect of our relational constructs on customer referrals. 


\section{Number of Services Purchased: Main Effects}

In this model, we found a positive effect of relationship age $(\beta=.24, p=.00)$. No effect of trust on the number of services purchased was found $(\beta=-.08, p=.07)$. Hence, no support was found for Hypothesis 1b. However, we found a significant positive main effect of affective commitment $(\beta=.05, p=.00$ ), thereby supporting Hypothesis $2 \mathrm{~b}$. Our results do not support Hypothesis $3 \mathrm{~b}$, as we found a negative nonsignificant coefficient for calculative commitment ( $\beta=-.01, p=.69)$. We did not find a significant positive effect of relationship satisfaction $(\beta=.06, p=.17)$. Hence, we find no support for Hypothesis $4 \mathrm{~b}$. The results further revealed a positive significant effect of payment equity ( $\beta=.06, p=.02)$. Thus, the analysis provides support for Hypothesis $5 \mathrm{~b}$.

\section{Number of Services Purchased: Moderator Effects}

Three of the five interaction effects in the model explaining the number of services purchased were found to be significant. One of the nonsignificant interaction effects is the one between relationship age and trust $(\beta=$ $.01, p=.83$ ). Thus, no support is provided for Hypothesis $6 \mathrm{a}$. Our results reveal a positive interaction effect between affective commitment and relationship age $(\beta=.05, p=$ .00 ). This result confirms Hypothesis $6 \mathrm{~b}$, which suggested that the positive effect of affective commitment is enhanced by relationship age. In contrast with Hypothesis $6 c$, we found a negative significant interaction effect between calculative commitment and relationship age $(\beta=$ $-.04, p=.05)$. Hence, Hypothesis $6 c$ is not supported. As hypothesized in Hypothesis $6 \mathrm{~d}$, we found that the effect of relationship satisfaction increases with relationship age ( $\beta$ $=.08, p=.03)$. A negative nonsignificant coefficient was found for the interaction effect between relationship age and payment equity ( $\beta=-.04, p=.12$ ). Hence, our results do not lend support for Hypothesis $6 \mathrm{e}$.

\section{DISCUSSION}

\section{Contributions to Relationship Marketing}

In this study, we examined the moderating effect of relationship age on the effect of three relational constructs not previously investigated: (1) affective commitment, (2) calculative commitment, and (3) payment equity. ${ }^{5} \mathrm{We}$ also examined two new dependent variables in this stream of research. Theoretically, we extend these studies by drawing from studies in social psychology to provide conceptual support for the moderating effect of relationship age. We also contribute to the literature by examining the effect of relational constructs on the number of services purchased. To our knowledge, this dependent variable has not been studied in prior research. By using archival data available from the insurance company, we were able to overcome the limitations inherent in same-source surveys for the measurement of independent and dependent variables (Simmons, Bickart, and Lynch 1993).

\section{Theoretical Discussion: Main Effects}

Our results on the antecedents of customer referrals are in line with prior research, as we find that trust, affective commitment, satisfaction, and payment equity are positively related to customer referrals. We found significant relationships only between the relational constructs of affective commitment and payment equity and the number of services purchased. The nonsignificant effect of trust is in line with prior research in the channel literature (e.g., Anderson et al. 1987; Doney and Cannon 1997; Verbeke et al. 1999). However, this is in contrast with the results of Hibbard et al. (2001). Perhaps this can be explained by the different measures of trust and the different contexts of the studies. The significant positive effect of affective commitment is in contrast with Gruen et al.'s (2000) study.

The nonsignificant effect of calculative commitment might be explained by our use of cross-sectional data. Perhaps calculative commitment would be an important antecedent of actual customer retention.

\section{Theoretical Discussion: Moderating Effect of Relationship Age}

No moderating effect of relationship age is found in the customer referral model. With respect to the number of services purchased, a moderating effect of relationship age on the effect of affective commitment, calculative commitment, and satisfaction is found. To our knowledge, this is the first study that provides support for the idea already suggested by Dwyer et al. (1987) that affective commitment becomes more important in later stages of the relationship. It also confirms that as the relationship ages and there is an increasing intimacy between the customers and the supplier, the increasing richness of the customers' impressions of the relationship leads to increasing confidence in the feelings of attachment with the supplier. This moderating effect of relationship age on the effect of satisfaction confirms prior research (e.g., Bolton 1998; Grayson and Ambler 1999; Rust et al. 1999) and also supports the claim of Jap (1999) that direct experiences from interactions with the supplier should be a more powerful predictor in later stages of the relationship. In contrast with statements in the literature (e.g., Dwyer et al. 1987; Jap 1999) and the findings of Grayson and Ambler (1999), we cannot find evidence for a time-dependent effect of trust. The context (business-to-consumer market) of our study 
might perhaps explain this discrepancy. This result might also be caused by the fact that trust is only important when choosing a new supplier. This might especially hold in the financial service industry because in this industry, many companies communicate a trustworthy image. The negative interaction effect between calculative commitment and relationship age is rather surprising. One speculative explanation for this result might be the following. Calculative commitment has a relative negative connotation. In later phases of the relationship, customers are more experienced and are more aware about this negative aspect of long-lasting relationships. Hence, they are less inclined to purchase more services because this further reduces their switching possibilities.

We end this discussion by speculating on the discrepancy between the customer referral model and the number of services purchased model with regard to the moderating effect of relationship age. One of the central premises underlying our hypotheses was that relationship age increases confidence in customers' beliefs about the supplier. This increasing confidence is indeed important when it concerns decisions that have important consequences, such as the purchase of new insurance policies. However, it might be less important when behavior has fewer direct consequences for the customer. Another explanation might be that the common-method variance in the customer referral model could have dampened the moderating effect of relationship age.

\section{Managerial Implications}

On the basis of our empirical results, the following implications for the management of customer relationships can be formulated. First, it may be worthwhile for firms to invest in relational constructs to increase customer referrals. Second, our results suggest that it may be worthwhile investing in affective commitment in all relationship phases also from a transactional perspective. This investment appears to be even more worthwhile in later phases of the relationship. Our results also suggest that investing in satisfaction pays off only in the long run. With respect to the effect of payment equity, companies should consider that customers with higher payment equity might be more inclined to purchase more services. However, as there is some preliminary evidence that the effect of payment equity is reduced in lengthy relationships, companies should be aware that using attractive prices as an important marketing instrument might have negative profit consequences in the long run.

\section{Research Limitations}

Some limitations of our study should be noted. First, and perhaps most important, our study only considers relationships of customers with a Dutch insurance company. As such, the external validity of our results can be considered to be limited. Generalizability of our results will only be established if additional studies consider our approach for other industries and other countries. Second, our study may suffer from the fact that it only uses crosssectional data. As a result, we cannot draw strong conclusions regarding the true dynamic effects. Third, the measurement of customer referrals could be improved. A possible improvement would be to measure the number of people who have become customers due to the spread of positive information from an individual customer. This would solve the common-method variance problems in the customer referral model.

\section{Directions for Future Research}

In addition to the issues arising from our limitations, the following research issues are important. First, in this study, a key premise underlying the moderating effect of relationship age is increasing customer confidence in one's impressions about the supplier as the relationship ages. We did not empirically test whether this is true in commercial relationships. Hence, future research could do this. We note, furthermore, that customer confidence could be only one explanation for the moderating effect of relationship age. Moreover, several articles have been published showing that relationship phase/age can make a difference in terms of the relationships between relational constructs and a variety of outcomes (e.g., Grayson and Ambler 1999; Jap and Ganesan 2000; Weiss and Kurland 1997), but we do not have the means to find out why this is so. Future research should focus more on this "why" question. In particular, studies are needed that enhance our understanding or explain the mixed results in the literature concerning trust. Second, our study is one of the few studies in the relationship marketing literature investigating how age moderates the effect of relational constructs on relational outcomes. There could be value in research that further investigates the different dynamics of short- and long-term relationships. In that respect, one could also employ the approach by Jap and Ganesan (2000) to measure relationship phase explicitly. Third, other dependent variables could be studied. An interesting variable in this respect is customer profitability, which also accounts for the price customers are willing to pay for certain products or services. Fourth, from a more technical perspective, mixture models can be formulated to accommodate customer heterogeneity (Wedel and Kamakura 1999). Such a model could be based on longitudinal data of the same customers so that clusters of individuals with similar behavior can be distinguished. 


\section{APPENDIX \\ Measurement Development of Constructs}

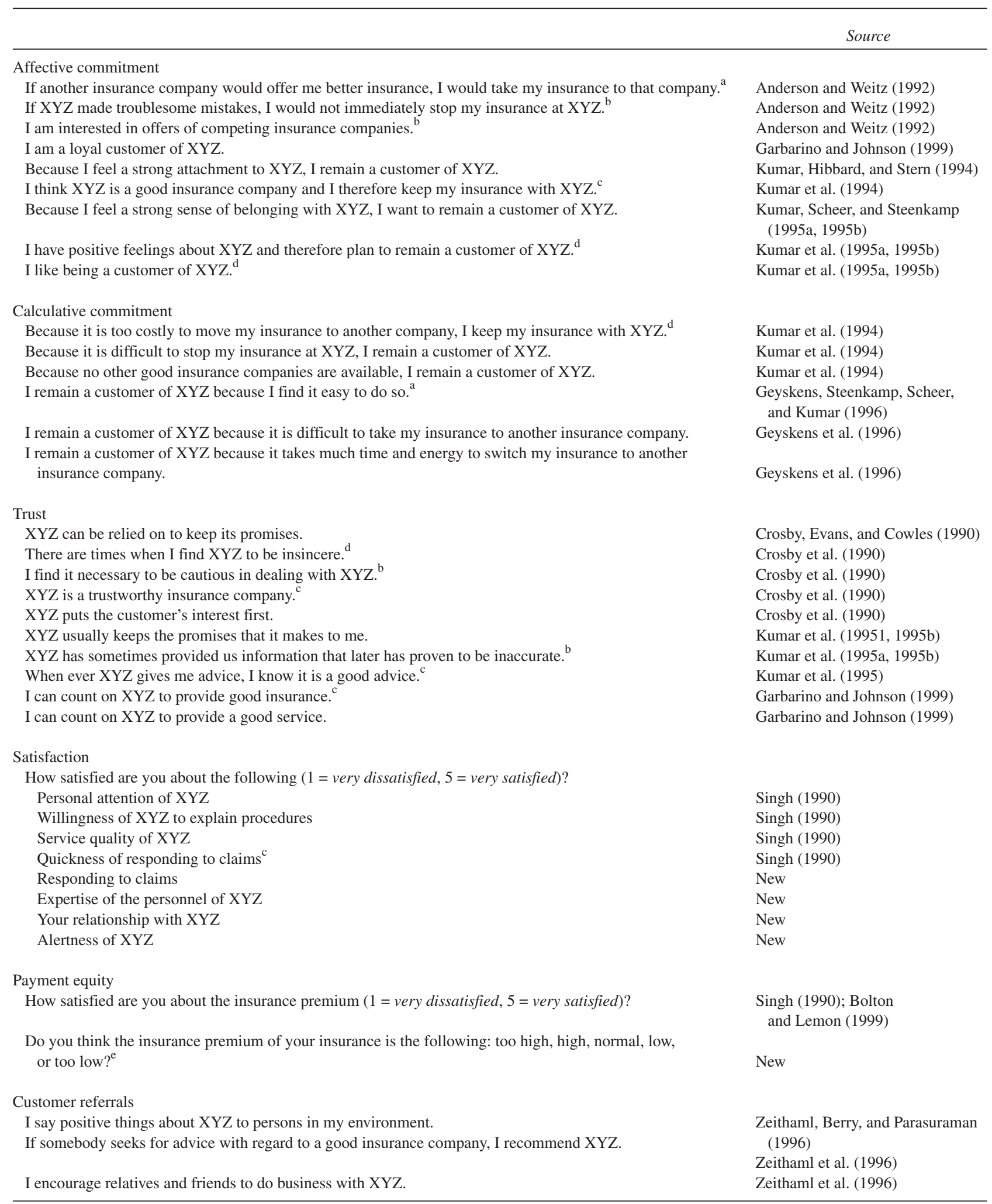

a. Item excluded after pretest based on coefficient alpha or item-to-total correlations.

b. Item excluded after pretest based on exploratory factor analysis.

c. Item excluded after pretest because of content reasons.

d. Item excluded after pretest based on confirmatory factor analysis.

e. Item included after pretest. 


\section{ACKNOWLEDGMENTS}

The authors gratefully acknowledge the financial and data support of a Dutch insurance company. This project has been supported by Vereniging Trustfonds Erasmus Universiteit Rotterdam in the Netherlands. The authors thank the editor, Rajan Varadarajan, and three anonymous reviewers for their helpful and detailed comments. They also acknowledge Inge Geyskens, Jan-Benedict Steenkamp, Peeter Verlegh, Gerrit van Bruggen, and Berend Wierenga for their helpful suggestions.

\section{NOTES}

1. By not taking this time-dependent nature into account, research might find a nonsignificant effect of trust. This can be explained as follows. As argued in the section on the moderating effect of relationship age, it is expected that trust is only important in short-term relationships. However, when researchers survey customers of a company, they will usually have a relatively small group of customers with short-term relationships and a relatively large group of customers with long-term relationships. (Note that this especially holds for industries with high retention rates.) Due to this skewed distribution of relationship age and the statement that trust will only have a positive effect in short-term relationships, the effect of trust might become insignificant for customers.

2 . In fact, most customers of the company under consideration report that price is the most important reason for starting to buy financial services from the company.

3. We chose ordinary least squares (OLS) and not a structural equation model in LISREL83, as previous research on the moderating effect of relationship age also used OLS or another regression-based technique to test for this moderating effect (Bolton 1998; Grayson and Ambler 1999; Jap and Ganesan 2000; Weiss and Kurland 1997). Because we wanted to compare our results with these studies, it was more appropriate to also use OLS with interaction effects. Furthermore, as the number of services purchased is a count measure, it was not suitable for use as a dependent variable in a LISREL model. For a comprehensive review of the Poisson regression model, see Long (1997, chap. 8).

4. We have also applied our analysis on customer referrals by using LISREL83. We first estimated the model as shown in Figure 1 for the total sample. The results of this model with only main effects match the results of our regression models. Subsequently, we applied a multigroup analysis in which we distinguished between customers with short-term relationships and customers with long-term relationship using a median split. Using this approach, we also do not find a moderating effect of relationship age. More details are available on request.

5. We acknowledge that Grayson and Ambler (1999) have investigated the moderating effect of relationship age on the effect of commitment. However, this study does not distinguish between affective and calculative commitment.

\section{REFERENCES}

Aiken, Leona S. and Stephen G. West. 1991. Multiple Regression: Testing and Interpreting Interactions. Thousand Oaks, CA: Sage.

Anderson, Erin and Barton A. Weitz. 1989. "Determinants of Continuity in Conventional Industrial Channels." Marketing Science 8 (4): 310323.

and 1992. "The Use of Pledges to Build and Sustain Commitment in Distribution Channel4s." Journal of Marketing Research 29 (1): 18-34.
— Leonard M. Lodish, and Barton A. Weitz. 1987. "Resource Allocation Behavior in Conventional Channels." Journal of Marketing Research 24 (1): 85-97.

Anderson, Eugene W., Claes Fornell, and Donald R. Lehmann. 1994. "Customer Satisfaction, Market Share and Profitability: Findings From Sweden." Journal of Marketing 58 (2): 53-66.

Anderson, James C. and David W. Gerbing. 1988. "Structural Equation Modeling in Practice: A Review and Recommended Two-Step Approach." Psychological Bulletin 103 (3): 411-423.

Bagozzi, Richard P. and Youyae Yi. 1988. "On the Evaluation of Structural Equation Models." Journal of the Academy of Marketing Science 16 (1): 74-94.

Baumgartner, Hans and Christian Homburg. 1996. "Applications of Structural Equation Modeling in Marketing and Consumer Research." International Journal of Research in Marketing 13 (2): 139161.

Bentler, Paul M. 1990. "Comparative Fit Indexes in Structural Models." Psychological Bulletin 107:238-246.

Berger, Ida E. and Andrew A. Mitchell. 1989. "The Effect of Advertising on Attitude Accessibility, Attitude Confidence, and Attitude Behavior Relationship." Journal of Consumer Research 16 (3): 269-279.

Berry, Leonard L. 1995. "Relationship Marketing in Services: Growing Interest, Emerging Perspectives." Journal of the Academy of Marketing Science 23 (4): 236-246.

Bettencourt, Lance A. 1997. "Customer Voluntary Performance: Customers as Partners in Service Delivery." Journal of Retailing 73 (3): 383-406.

Bickart, Barbara A. 1993. "Carryover and Backfire Effects in Marketing Research.” Journal of Marketing Research 30 (1): 52-62.

Blattberg, Robert C., Rashi Glazer, and John D. C. Little. 1994. Marketing Information Revolution. Boston: Harvard Business School Press.

Bolton, Ruth N. 1998. "A Dynamic Model of the Duration of the Customer's Relationship With a Continuous Service Provider: The Role of Satisfaction." Marketing Science 17 (1): 45-65.

and Katherine N. Lemon. 1999. "A Dynamic Model of Customers' Usage of Services: Usage as an Antecedent and Consequence of Satisfaction." Journal of Marketing Research 36 (2): 171-186.

_ P. K. Kannan, and Mathew D. Bramlett. 2000. "Implications of Loyalty Program Membership and Service Experiences for Customer Retention and Value." Journal of the Academy of Marketing Science 28 (1): 95-108.

Brown, James R., Robert F. Lusch, and Carolyn Y. Nicholson. 1995. "Power and Relationship Commitment: Their Impact on Marketing Channel Member Performance." Journal of Retailing 71 (4): 363392.

Churchill, Gilbert A., Jr. 1979. "A Paradigm for Developing Better Measures of Marketing Constructs.” Journal of Marketing Research 16 (1): 64-73.

Crosby, Lawrence A., Kenneth R. Evans, and Deborah Cowles. 1990. "Relationship Quality in Services Selling: An Interpersonal Influence Perspective." Journal of Marketing 54 (3): 68-81.

Dick, Allan S. and Kunal Basu. 1994. "Customer Loyalty: Toward an Integrated Conceptual Framework." Journal of the Academy of Marketing Science 22 (2): 99-113.

Doney, Patricia M. and Joseph P. Cannon. 1997. "An Examination on the Nature of Trust in Buyer-Seller Relationships." Journal of Marketing 61 (2): $35-71$

Dwyer, Robert F., Paul H. Schurr, and Sejoh Oh. 1987. "Developing Buyer-Seller Relationships.” Journal of Marketing 51 (2): 11-27.

Ganesan, Shankar. 1994. "Determinants of Long-Term Orientation in Buyer-Seller Relationships." Journal of Marketing 59 (2): 1-19.

Garbarino, Ellen and Mark S. Johnson. 1999. "The Different Roles of Satisfaction, Trust and Commitment in Customer Relationships." Journal of Marketing 63 (2): 70-87.

Gerbing, David W. and James C. Anderson. 1988. "An Updated Paradigm for Scale Development Incorporating Unidimensionality and Its Assessment.” Journal of Marketing Research 25 (2): 186-192.

Geyskens, Inge, Jan-Benedict E. M. Steenkamp, Lisa K. Scheer, and Nirmayala Kumar. 1996. "The Effects of Trust and Interdependence on Relationship Commitment: A Trans-Atlantic Study." International Journal of Research in Marketing 13 (4): 303-317. 
$\longrightarrow$ - $\longrightarrow$ and 1999. "A Meta-Analysis of Satisfaction in Marketing Channel Relationships." Journal of Marketing Research 36 (2): 223-238.

Gill, Michael J., William B. Swann Jr., and David H. Silvera. 1998. “On the Genesis of Confidence." Journal of Personality and Social Psychology 75 (5): 1101-1114.

Grayson, Kent and Tim Ambler. 1999. "The Dark Side of Long-Term Relationships in Marketing Services." Journal of Marketing Research 36 (1): 132-141.

Gruen, Thomas W., John O. Summers, and Frank Acito. 2000. "Relationship Marketing Activities, Commitment, and Membership Behaviors in Professional Associations." Journal of Marketing 64 (3): 34-49.

Gundlach, Greg T., Ravi S. Achrol, and John T. Mentzer. 1995. "The Structure of Commitment in Exchange." Journal of Marketing 59 (1): 78-92.

Gwinner, Kevin P., Dwayne D. Gremler, and Mary Jo Bitner. 1999. "Relational Benefits in Service Industries: The Customers' Perspective." Journal of the Academy of Marketing Science 26 (2): 101-114.

Hair, Joseph F., Rolph E. Anderson, Ronald L. Tatham, and William C. Black. 1998. Multivariate Data Analysis. Upper Saddle River, NJ: Prentice Hall.

Hibbard, Jonathan D., Nirmayala Kumar, and Louis W. Stern. 2001. "Examining the Impact of Destructive Acts in Marketing Channel Relationships.” Journal of Marketing Research 38 (1): 45-61.

Jap, Sandy D. 1999. "Pie-Expansion Efforts: Collaboration Processes in Buyer-Supplier Relationships." Journal of Marketing Research 35 (4): 461-475.

- and Shankar Ganesan. 2000. "Control Mechanisms and the Relationship Life Cycle: Implications for Safeguarding Specific Investments and Developing Commitment." Journal of Marketing Research 37 (2): 227-245.

Jöreskog, Karl and Dag Sörbom. 1993. LISREL 83 Structural Equation Modeling With the SIMPLIS Command Language. Chicago: SSI Scientific Software International.

Kamakura, Wagner A., Sridhar N. Ramaswami, and Rajendra K. Srivastava. 1991. "Applying Latent Trait Analysis in the Evaluation of Prospects for Cross Selling of Financial Services." International Journal of Research in Marketing 8 (4): 329-349.

Klemperer, Paul. 1995. "Competition When Consumers Have Switching Costs: An Overview With Applications to Industrial Organization, Macro Economics and International Trade." Review of Economic Studies 62 (4): 515-539.

Kumar, Nirmayala, Louis W. Stern, and Ravi S. Achrol. 1992. "Assessing Reseller Performance From the Perspective of the Supplier." Journal of Marketing Research 29 (2): 238-253.

_ Jonathan D. Hibbard, and Louis W. Stern. 1994. "The Nature and Consequences of Marketing Channel Intermediary Commitment.” Report No. 94-115, Marketing Science Institute Working Paper.

_ Lisa K. Scheer, and Jan-Benedict E. M. Steenkamp. 1995a. "The Effects of Supplier Fairness on Vulnerable Resellers." Journal of Marketing Research 32 (1): 54-65.

— $—$, and 1995b. "The Effects of Perceived Interdependence on Dealer Attitudes." Journal of Marketing Research 32 (3): $348-357$.

Lichtenstein, Donald R., Nancy M. Ridgway, and Richard G. Netemeyer. 1993. "Price Perceptions and Consumer Shopping Behavior: A Field Study." Journal of Marketing Research 30 (2): 234-245.

Long, J. Scott. 1997. Regression Models for Categorical and Limited Dependent Variables. Advanced Quantitative Techniques in the Social Sciences Series 7. Thousand Oaks, CA: Sage.

Mittal, Vikas and Wagner A. Kamakura. 2001. "Satisfaction, Repurchase Intent and Repurchase Behavior: Investigating the Moderating Effect of Customer Characteristics." Journal of Marketing Research 38 (1): 131-142.

Moorman, Christine, Gerald Zaltman, and Rohit Desphandé. 1992. "Relationships Between Providers and Users of Marketing Research: The Dynamics of Trust Within and Between Organizations." Journal of Marketing Research 29 (3): 314-329.

Morgan, Robert M. and Shelby D. Hunt. 1994. "The Commitment-Trust Theory of Relationship Marketing." Journal of Marketing 58 (3): 2038 .
Nilssen, Tore. 2000. "Consumer Lock-in With Asymmetric Information.” International Journal of Industrial Organization 18 (4): 641666

Odekerken-Schröder, Gaby. 1999. "The Role of the Buyer in Affecting Buyer-Seller Relationships: Empirical Studies in a Retail Context." Doctoral dissertation, University of Maastricht.

Pieters, Rik G. M. and B. Verplanken. 1995. "Intention-Behavior Consistency: Effects of Consideration Set Size, Involvement and Need for Cognition." European Journal of Social Psychology 35:531-541.

Reinartz, Werner J. and Vijay Kumar. 2000. "On the Profitability of Long-Life Customers in a Noncontractual Setting: An Empirical Investigation and Implications for Marketing." Journal of Marketing 64 (4): 17-35.

Rust, Roland T., Jeffrey Inman, Jianmin Jia, and Anthony Zahorik. 1999. "What You Don't Know About Customer Perceived Quality: The Role of Customer Expectation Distributions." Marketing Science 18 (1): 77-92.

, Valarie A. Zeithaml, and Katherine N. Lemon. 2000. Driving Customer Equity: How Customer Lifetime Value Is Reshaping Corporate Strategy. New York: Free Press.

Shapiro, Carl and Hal R. Varian. 1999. Information Rules: A Strategic Guide to the Network Economy. Boston: Harvard Business School Press.

Sheth, Jagdish N. and Atul Parvatiyar. 1995. "Relationship Marketing in Consumer Markets: Antecedents and Consequences." Journal of the Academy of Marketing Science 23 (4): 255-271.

Simmons, Carolyn J., Barbara A. Bickart, and John G. Lynch Jr. 1993. "Capturing and Creating Public Opinion Research." Journal of Consumer Research 20 (2): 316-329.

Singh, Jagdip. 1990. "Voice, Exit, and Negative Word-of-Mouth Behaviors: An Investigation Across Three Service Categories." Journal of the Academy of Marketing Science 18 (1): 1-15.

Steenkamp, Jan-Benedict and Hans C. M. van Trijp. 1991. "The Use of LISREL in Validating Marketing Constructs.” International Journal of Research in Marketing 8 (4): 283-299.

Swann, William B. Jr. and Michael J. Gill. 1997. "Confidence in Person Perception: Do We Know What We Think About Our Relationship Partners?" Journal of Personality and Social Psychology 73 (4): 747757

Szymanski, David M. and David H. Henard. 2001. "Customer Satisfaction: A Meta-Analysis of the Empirical Evidence." Journal of the Academy of Marketing Science 29 (1): 16-35.

Verbeke, Willem I.J.M., Hans Veldkamp, Richard P. Bagozzi, and Paul W. Farris. 1999. "Is Trust a Key-Concept in Explaining Resource Allocations by Retailers?" Working paper, Erasmus University, Rotterdam.

Wedel, Michel and Wagner A. Kamakura. 1999. Market Segmentation: Conceptual and Methodological Foundations. Boston: Kluwer Academic.

Weiss, Allan M. and Nancy Kurland. 1997. "Holding Distribution Channel Relationships Together: The Role of Transaction-Specific Assets and Length of Prior Relationship." Organization Science 8 (6): 612623.

White, Herbert. 1980. "A Heteroskedasticity-Consistent Covariance Matrix and a Direct Test for Heteroskedasticity." Econometrica 48:817838.

Zeithaml, Valarie A., Leonard L. Berry, and A. Parasuraman. 1996. "The Behavioral Consequences of Service Quality.” Journal of Marketing 60 (2): 31-46.

\section{ABOUT THE AUTHORS}

Peter C. Verhoef is a postdoctoral researcher affiliated with the Department of Marketing and Organization in the School of Economics at Erasmus University, Rotterdam. He is also a member of the Erasmus Research Institute in Management (ERIM). In 2001, he received his Ph.D. in marketing from Erasmus University. In his dissertation, he investigated how companies can affect the lifetime value of customers. His research interests include 
customer relationship management, waiting times, and private labels. His work has been or will be published in the Journal of Consumer Psychology, Journal of Retailing, Decision Support Systems, and various other journals.

Philip Hans Franses is a professor of applied econometrics at the Econometric Institute and a professor of marketing research in the Department of Marketing and Organization, both at Erasmus University, Rotterdam. His research interests include applied econometrics, marketing, empirical finance, political science, and environmetrics. He publishes on these topics in various journals.

Janny C. Hoekstra is a professor in direct marketing at the University of Groningen. Her research interests include the development of the marketing concept, market orientation, customer lifetime value, direct marketing, and e-commerce. She has published papers in the Journal of Retailing, Industrial Marketing Management, European Journal of Marketing, Journal of Direct Marketing, and Journal of Market-Focused Management, among others. 